\title{
SOLAR THERMAL POWER PLANTS IN THE WORLD: THE EXPERIENCE OF DEVELOPMENT AND OPERATION
}

\author{
Nilufar AVEZOVA ${ }^{1}$, Azizboy KHAITMUKHAMEDOV ${ }^{1 *}$, Abdurauf USMANOV ${ }^{l}$ \\ ${ }^{1}$ International Solar Energy Institute, Tashkent, 100084, Uzbekistan \\ *avezov@uzsci.net; azizboykh90@gmail.com
}

\begin{abstract}
The main areas of large-scale development of solar energy are:

- conversion of solar energy into low-grade heat, and using the latest in heating systems of residential, municipal facilities, public and industrial buildings that consume energy such as temperature capacity;

- conversion of solar energy into electricity through photovoltaic and thermodynamic converters.

This report provides short information of the dynamics of the creation and operation of solar power plants (SPP) with the thermodynamic conversion, and the criteria for reducing cost of electricity produced from them.

Key words: renewable energy sources, solar energy, solar power plant, parabolic trough, integrated solar combined cycle
\end{abstract}

\section{INTRODUCTION}

In the world practice a view to obtaining electrical energy with the help of thermodynamic conversion of solar energy (SE), the following technologies are used: parabolic through collector (PTC), linear Fresnel, dish Stirling and solar tower [1].

On the basis of the abovementioned technologies today in the developed countries of the world are created big capacities solar power plants. In [1-3] are considered indicators the operational SPP solar tower and parabolic trough which capacity $100 \mathrm{MW}$ and above.

SPP with the thermodynamic conversion of SE operated mostly in the range of $35^{\circ} \mathrm{S}-35^{\circ} \mathrm{N}$, but on research of executed in [4] PTC with the orientation of the optical axis of the north-south for the winter declination of the Sun can also be used in areas between $40^{\circ} \mathrm{S}-40^{\circ} \mathrm{N}$.

Together with it, on a row with the purely thermodynamic transformation of SPP, are created integrated solar combined cycle (ISCC) power plants. In table 1, the lists of the ISCC with PTC installed in the period from 2009 to 2015 . Accordingly, in table 2 is a list of the planned ISCC to 2020 worldwide. 
Table 1. List of operational ISCC based on PTC in the world

\begin{tabular}{|c|c|c|c|c|c|}
\hline Project Name & $\begin{array}{c}\text { Electric } \\
\text { power, MWe }\end{array}$ & $\begin{array}{c}\text { Solar } \\
\text { Capacity } \\
\text { MWe }\end{array}$ & Country & Technology & $\begin{array}{c}\text { Operation } \\
\text { year }\end{array}$ \\
\hline Martin & 3705 & 75 & USE & Parabolic Trough & 2010 \\
\hline Victorville & 563 & 50 & USE & Parabolic Trough & 2013 \\
\hline Agua Prieta & 480 & 31 & Mexico & Parabolic Trough & 2015 \\
\hline $\begin{array}{c}\text { Ain Beni } \\
\text { Mathar }\end{array}$ & 472 & 20 & Morocco & Parabolic Trough & 2010 \\
\hline Yazd & 430 & 67 & Iran & Parabolic Trough & 2009 \\
\hline Kuraymat & 140 & 20 & Egypt & Parabolic Trough & 2011 \\
\hline Hassi R'Mel & 130 & 25 & Algeria & Parabolic Trough & 2011 \\
\hline Archimede & 130 & 5 & Italy & Parabolic Trough & 2010 \\
\hline
\end{tabular}

According to the data [5], in the world leaders in terms of development and operation of SPP are USA, Spain, South Africa, Morocco, Chile, China, India, and Israel. The total number of operation and under construction until 2019 SPP are shown in Table 3.

As can be seen from Table 1 and Table 2, the capacity of solar part of ISCC is from 5 to $20 \%$ of the total capacity of the whole plant [3].

Table 2. List of planned ISCC based on PTC until 2020 in the world

\begin{tabular}{|c|c|c|c|c|}
\hline Project Name & $\begin{array}{c}\text { Electric power, Solar Capacity } \\
\text { MWe }\end{array}$ & Country & Technology \\
\hline MWe & 1200 & 100 & Tunisia & Parabolic Trough \\
\hline $\begin{array}{c}\text { Waad Al Shamal ISCC } \\
\text { Plant }\end{array}$ & 1050 & 50 & $\begin{array}{c}\text { Saudi } \\
\text { Arabia }\end{array}$ & Parabolic Trough \\
\hline Palmdale & 555 & 62 & USA & Parabolic Trough \\
\hline Hassi R'Mel II & 400 & 70 & Algeria & Parabolic Trough \\
\hline Meghaier & 400 & 75 & Algeria & Parabolic Trough \\
\hline Naama & 400 & 70 & Algeria & Parabolic Trough \\
\hline Al Abdaliyah ISCC & 280 & 60 & Kuwait & Parabolic Trough \\
\hline
\end{tabular}


Table 3. Operational and planned solar power plants based on the thermodynamic conversion of solar energy (until 2019) in the world

\begin{tabular}{|c|c|c|c|c|c|c|c|c|}
\hline Project Name & Technology & $\begin{array}{c}\text { Total } \\
\text { Capacity } \\
\text { MW }\end{array}$ & $\begin{array}{c}\text { Solar } \\
\text { Capacity } \\
\text { MWe }\end{array}$ & Country & $\begin{array}{c}\text { Current } \\
\text { Status }\end{array}$ & $\begin{array}{l}\text { Storage } \\
\text { (Hours) }\end{array}$ & $\begin{array}{c}\text { Actual } \\
\text { Commercial } \\
\text { Operation Date }\end{array}$ & $\begin{array}{r}2015 \text { USD } \\
\text { (constant } \\
\text { millions) }\end{array}$ \\
\hline Nevada Solar One & Parabolic Trough & & 64 & USA & Operation & 0.5 & $01 / 06 / 07$ & $\$ 258$ \\
\hline Spain PT w/ 7.5 h storage & Parabolic Trough & & 50 & Spain & Operation & 7.5 & $01 / 12 / 10$ & $\$ 405$ \\
\hline Martin Next Generation Solar Energy Center & Parabolic Trough & & 75 & USA & Operation & & $01 / 12 / 10$ & $\$ 462$ \\
\hline Shams 1 & Parabolic Trough & & 100 & UAE & Operation & & $17 / 03 / 13$ & $\$ 588$ \\
\hline Solana & Parabolic Trough & & 280 & USA & Operation & 6 & $09 / 10 / 13$ & $\$ 2,041$ \\
\hline Enerstar Villena & Parabolic Trough & & 50 & Spain & Operation & & $01 / 11 / 13$ & $\$ 309$ \\
\hline Genesis Solar 2 & Parabolic Trough & & 125 & USA & Operation & & $30 / 11 / 13$ & $\$ 499$ \\
\hline Ivanpah Solar Electric Generating Station I & Tower & & 126 & USA & Operation & & $30 / 01 / 14$ & $\$ 732$ \\
\hline Ivanpah Solar Electric Generating Station II & Tower & & 133 & USA & Operation & & $30 / 01 / 14$ & $\$ 732$ \\
\hline Ivanpah Solar Electric Generating Station III & Tower & & 133 & USA & Operation & & $30 / 01 / 14$ & $\$ 732$ \\
\hline Genesis Solar 1 & Parabolic Trough & & 125 & USA & Operation & & $01 / 03 / 14$ & $\$ 499$ \\
\hline Megha & Parabolic Trough & & 50 & India & Operation & 8 & $12 / 11 / 14$ & $\$ 127$ \\
\hline Mojave Solar Project & Parabolic Trough & & 280 & USA & Operation & & $01 / 12 / 14$ & $\$ 1,633$ \\
\hline Crescent Dunes & Tower & & 110 & USA & Operation & 10 & $01 / 01 / 15$ & $\$ 964$ \\
\hline $\mathrm{KaXu}$ Solar One & Parabolic Trough & & 100 & S. Africa & Operation & 2.5 & $02 / 03 / 15$ & $\$ 843$ \\
\hline Bokpoort & Parabolic Trough & & 50 & S. Africa & Operation & 9.3 & $17 / 12 / 15$ & $\$ 323$ \\
\hline Khi Solar One & Tower & & 50 & S. Africa & Operation & 2 & $01 / 01 / 16$ & $\$ 432$ \\
\hline Noor I & Parabolic Trough & & 160 & Morocco & Operation & 3 & $04 / 02 / 16$ & $\$ 1,163$ \\
\hline Atacama-1 (Planta Solar Cerro Dominador) & Tower & 210 & 110 & Chile & Construction & 17.5 & $01 / 06 / 17$ & $\$ 1,275$ \\
\hline Shagaya CSP Project - Phase One & Parabolic Trough & & 50 & Kuwait & Construction & 9 & $01 / 07 / 17$ & $\$ 257$ \\
\hline Noor II & Parabolic Trough & & 200 & Morocco & Construction & 7 & $01 / 07 / 17$ & $\$ 1,100$ \\
\hline Akesai Solar Thermal Power Plant & Parabolic Trough & & 50 & China & Construction & 15 & $01 / 08 / 17$ & $\$ 318$ \\
\hline Xina Solar One & Parabolic Trough & & 100 & S. Africa & Construction & 5 & $01 / 09 / 17$ & $\$ 652$ \\
\hline Noor III & Tower & & 150 & Morocco & Construction & 7 & $01 / 10 / 17$ & $\$ 861$ \\
\hline Qinghai Delingha (CGN) Phase I & Parabolic Trough & & 50 & China & Construction & 7 & $31 / 12 / 17$ & $\$ 397$ \\
\hline Ashalim Plot B (Megalim Solar Power) & Tower & & 121 & Israel & Construction & & $31 / 12 / 17$ & $\$ 735$ \\
\hline Kathu CSP & Parabolic Trough & & 100 & S. Africa & Construction & 4.5 & $01 / 06 / 18$ & $\$ 716$ \\
\hline Ashalim Plot A (Negev Energy) & Parabolic Trough & & 110 & Israel & Construction & 4.5 & $01 / 07 / 18$ & $\$ 980$ \\
\hline Ilanga CSP 1 (Karoshoek Solar One) & Parabolic Trough & & 100 & S. Africa & Construction & 5 & $01 / 10 / 18$ & $\$ 592$ \\
\hline
\end{tabular}


International Journal of Energy and Smart Grid

Table 4 shows the technical and economic indicators of the solar power plant with thermodynamic conversion based on different technologies.

Table 4. Solar thermal power plants type

\begin{tabular}{|c|c|c|c|c|}
\hline & \multicolumn{2}{|c|}{ Line Focusing } & \multicolumn{2}{c|}{ Point Focusing } \\
\hline Technology & Parabolic Through & Fresnel & Solar Tower & Dish \\
\hline Capacity (MW) & $10 \sim 200$ & $10 \sim 200$ & $10 \sim 100$ & $0.1 \sim 1$ \\
\hline Efficiency $(\%)$ & $11 \sim 16$ & 13 & $7 \sim 20$ & $12 \sim 25$ \\
\hline Temperature $\left({ }^{\circ} \mathrm{C}\right)$ & $350 \sim 415$ & $270 \sim 500$ & $250 \sim 565$ & $750 \sim 800$ \\
\hline Investment $(\mathrm{USD} / \mathrm{kW})$ & $3,000 \sim 6,500$ & $2,500 \sim 5,500$ & $4,000 \sim 6,000$ & $4,000 \sim 10,000$ \\
\hline Status & Commercialized & Commercialized & Commercialized & Prototype \\
\hline Market Share & $90 \sim 93 \%$ & Small & $5 \sim 7 \%$ & Small \\
\hline Remarks & HTF, Molten salt & $\begin{array}{c}\text { Water/steam cycle } \\
\text { (Clean, Min. Heat } \\
\text { exchanger) }\end{array}$ & $\begin{array}{c}\text { Air, Water, Molten salt } \\
\text { (gas turbine \& CC) }\end{array}$ & $\begin{array}{c}\text { Rankine cycle/Stirling } \\
\text { engine }\end{array}$ \\
\hline
\end{tabular}

As seen in table 4, solar thermal power plants based on PTC dominate around the world.

\section{MATERIAL AND METHOD}

Created in the world ISCC based on PTC are generally designed as in fig. 1. ISCC consists of the gas turbine with natural gas as combustible fuel, heat recovery steam generator (HRSG), steam turbine, cooling system and the solar field from PTC. The plants presented in Table 1 and 2 are under construction according to the schematic diagram provided on fig. 1 [6].

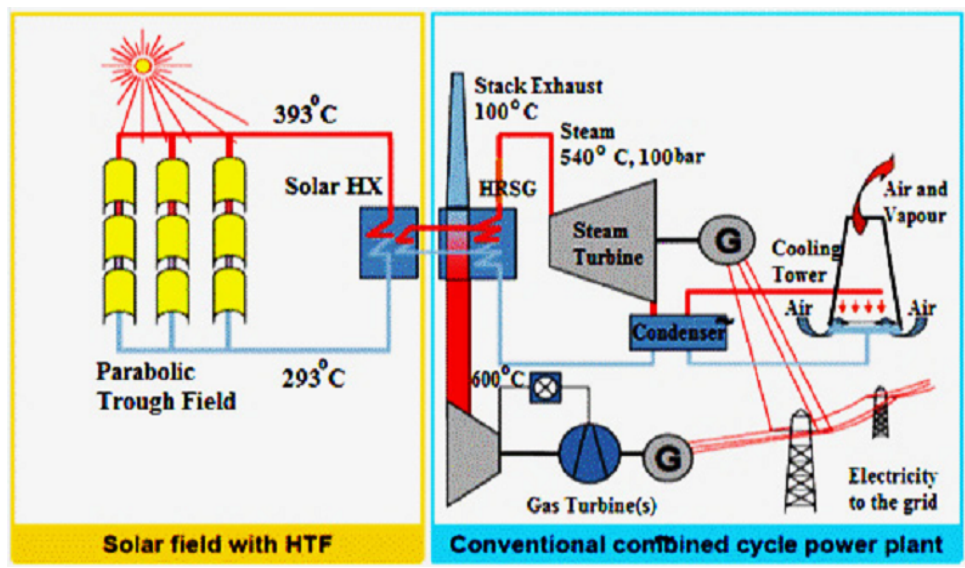

Figure 1. ISCC system schematic diagram

Generalization of operating experience shows that in ISCC, the electric solar capacity does not account for more than $15 \%$ of the electric steam turbine capacity of the ISCC. This limitation is necessary in order to avoid considerable negative effects on the Rankine cycle efficiency during times of no or low solar irradiation. 
The steam turbine of the ISCC has to be designed for maximum solar heat, i.e. it will be larger than in a $\mathrm{CC}$ with the same gas turbine. Hence, at operating points with no solar irradiation the steam turbine will operate in part load conditions whereas in the CC it would operate at full load. Usually, from $100 \%$ to $85 \%$ of the nominal load the efficiency of the steam turbine is approximately constant. Hence, by limiting the Electric Solar Capacity to $15 \%$ the negative effects of increased part load become negligible [7].

As it is specified in $[8,9]$, now the electricity produced by large photovoltaic systems in Germany costs cheaper, than 9 Euro cents for $\mathrm{kWh}$ that is comparable with the electric power developed by coal and gas thermal power plants at prime cost from 5 to 10 Euro cents for $\mathrm{kWh}$. Prime cost of the nuclear energy developed by the modern nuclear power plants (NPP) according to them makes 11 cents for $\mathrm{kWh}$.

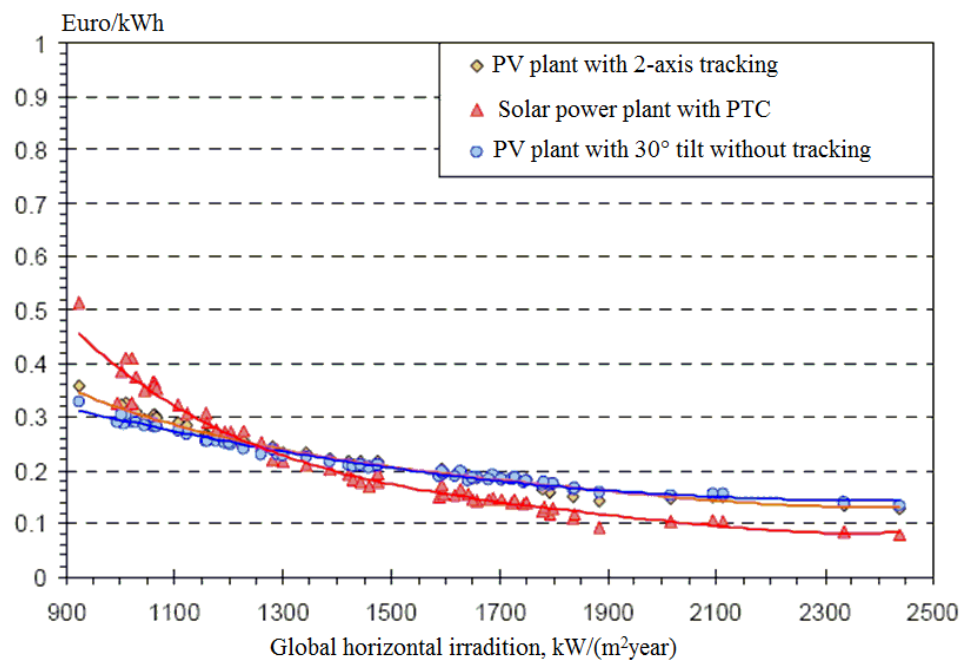

Figure 2. Cost price of the generated power energy on solar power plants

On the chart 1 is shown Global CSP Capacity $\left(\mathrm{MW}_{\mathrm{e}}\right)$ by technology and status [10].

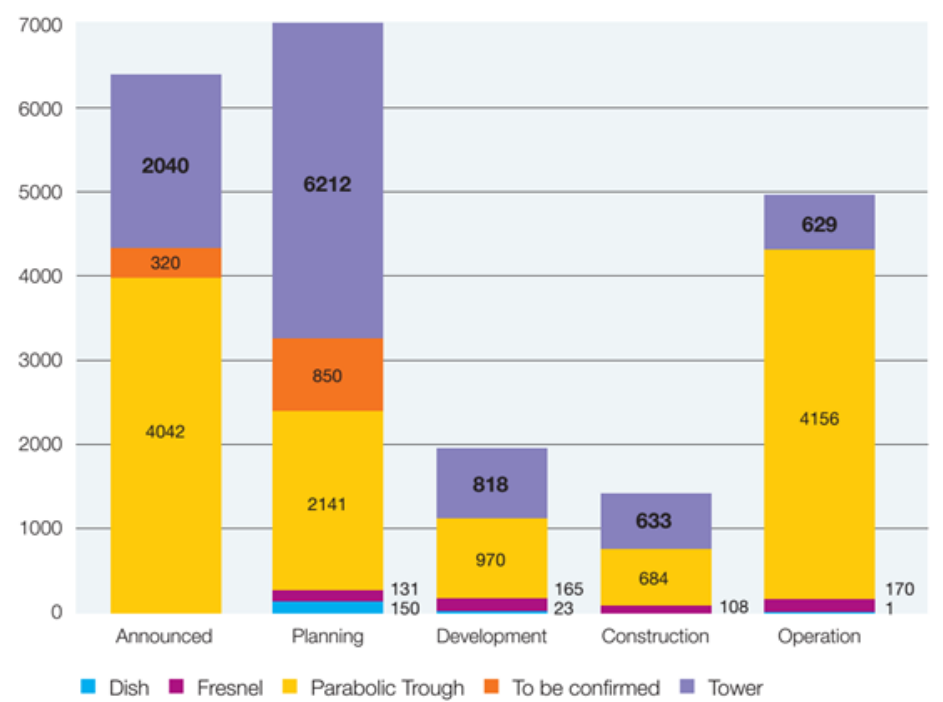

Chart 1. Global power of CSP $\left(M_{\mathrm{e}}\right)$ on technology and the status 
Cost price of the electric energy, generated by solar thermal power plants is in range of 12-18 Euro cents for $\mathrm{kWh}$ that does it to one of the least expensive options for increase in the generating capacities (Fig. 2.). According to forecasts cost price of the electric energy generated on solar thermal power plants in Central and Southern Europe, as expected, will decrease to 8-12 Euro cents for kWh by 2030 (fig. 3) [9].

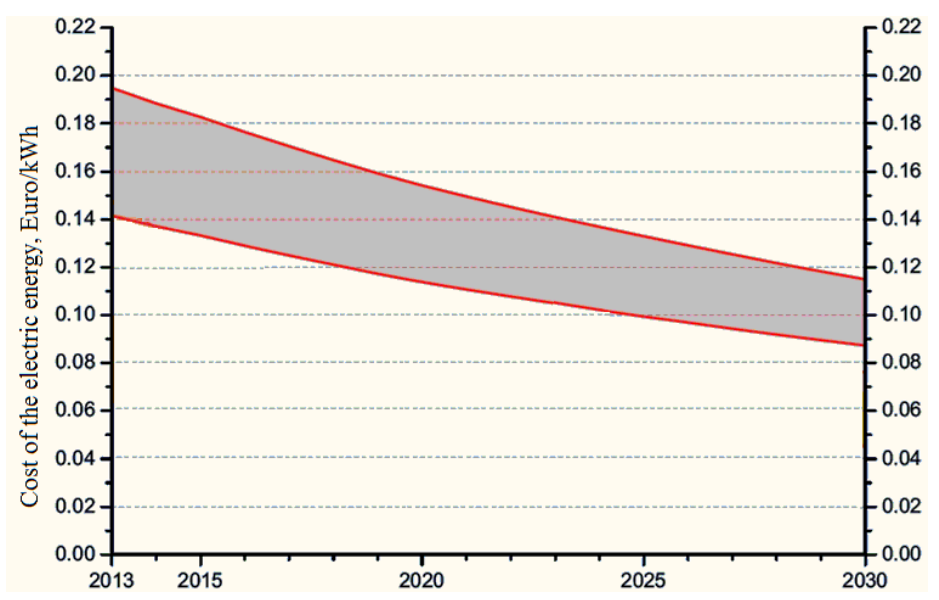

Figure 3. Forecast of decrease in cost price of electrical energy generated in solar thermal power plants at solar radiation in $2000 \div 2500\left(\mathrm{~kW} /\left(\mathrm{m}^{2} \mathrm{y}\right)\right)$

Table 5 lists the current and expected costs of the main systems of a typical solar thermal power plant [11].

Table 5. Drivers for cost reduction in ISCC

\begin{tabular}{|l|c|c|}
\hline & Today & $\mathbf{2 0 2 5}$ \\
\hline $\begin{array}{l}\text { A) Solar field incl. HTF } \\
\left(€ \mathrm{~m}^{2}\right)\end{array}$ & $160-250$ & $100-160$ \\
\hline $\begin{array}{l}\text { B) Thermal Storage } \\
\left(€ / \mathrm{kWh}_{\text {th }}\right)\end{array}$ & $26-30$ & $18-21$ \\
\hline C) PowerBlock $\left(€ / \mathrm{kW}_{\mathrm{e}}\right)$ & $720-765$ & $700-790$ \\
\hline D) System Efficiency & $15 \%-17 \%$ & $18 \%-20 \%$ \\
\hline
\end{tabular}

The following criteria is expected to reduce costs by table 5:

\section{A) Solar Field}

1. Collector with larger Aperture (trough)

2. Improved optics through higher accuracy heliostats, improved field layout (tower)

3. Advanced assembly procedure, industrialized assembly, industrial automatization in manufacturing; (sub) supplier standards; standardized design

4. Higher reflectivity, higher cleanliness

5. Improved durability

6. Improved absorber coating

7. Wireless power supply and control (heliostat)

8. Improved optics through higher accuracy heliostats, improved field layout (tower)

9. Improved O\&M procedures

B) Thermal Storage 
1. Direct storage concept $(\mathrm{HTF}=$ Storage Medium $)$

2. Higher temperature difference

3. Adapted thermal storage materials

4. Standardized design; sub-supplier design standards

5. Advanced charging and discharging, improved operation strategies in general

\section{C) Power Block}

1. Higher cycle efficiency

2. Improved hybridization concept

3. Larger power block

4. Standardized design

D) System Efficiency

1. Higher process temperature

2. Lower parasitic consumption (higher temperature through larger aperture and other HTF; at the tower: gravitational pressure loss recovery)

3. Adapted turbine design (for daily start-up)

4. Improved control and O\&M strategies/procedures

Based on the foregoing can be stated that the use of ISCC power plant with PTC in countries with hot climate, today the world is one of the perspective ways of for the production of electricity as from the power energy point of view and from an economic point of view.

Today in the republic is developed the Roadmap "Republic of Uzbekistan: Solar Energy Development" in assistance with the Asian Development Bank (ADB). According to the optimistic scenario in Uzbekistan until 2031, it will be installed 4 GW capacity of solar power plants, where is planned construction of solar PV plants and ISCC based on PTC. Based on the abovementioned Roadmap is scheduled construction of the first ISCC in Navoi region with a total capacity of $130 \mathrm{MW}$ $[12,13]$.

Taking into account the our country climatic conditions by us proposed the following schemetechnological solution for the creation of ISCC based on PTC in the Republic.

In fig. 4 it is presented ISCC based on PTC which consists of two gas turbine units, two HRSG, solar heat steam generator, steam turbine unit and the solar field from PTC [14].

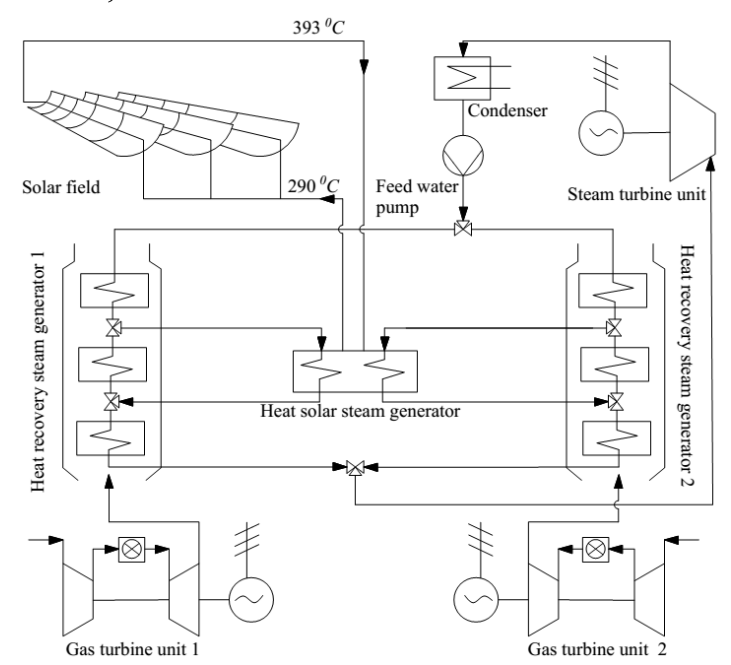

Figure 4. ISCC system schematic diagram based on PTC 
Designed power plants of this type can work in three modes: ISCC mode at solar hours (even with one gas turbine), conventional combined cycle mode at non solar hours and gas turbine mode when the steam turbine is not functioning.

According to results of preliminary calculations, in the presence of the territory for the construction of the solar field (at the rate of 2 hectares per $1 \mathrm{MW}$ ) modernization of thermal power plants with CCGT (Navoi, Tashkent and Talimardjan), the total capacity of about $2 \mathrm{GW}$ today, combining them with solar field of ISCC power plant with PTC ( 14\% efficiency), will provide the SE share from 13 to $15 \%$ of the total plant capacity and natural gas savings will be from $418 \mathrm{mln} . \mathrm{m}^{3}$ to $482 \mathrm{mln} . \mathrm{m}^{3}$ per year, which in turn will lead to a reduction in $\mathrm{CO}_{2}$ emissions per year from 106.1 mln. $\mathrm{kg}$ to $139.2 \mathrm{mln}$. $\mathrm{kg}$.

\section{CONCLUSION}

Our future, substantially, depends on application of technological innovations. According to forecasts, within the next decades value and a share of SE in the general process of energy production will grow rapidly. These technologies reduce not only $\mathrm{CO}_{2}$ global emission, but also give necessary stability to power energy, doing it less dependent on limited reserves of fossil fuel.

\section{REFERENCES}

[1] National Renewable Energy Laboratory (NREL). Renewable Energy Data Book. 2013 http://www.nrel.gov/docs/fy15osti/62580.pdf

[2] Ismatkhodgaev S.K., e.g. Advanced Technologies of Development of Power Engineering and Energy Supply of the Republic Economy, Applied Solar Energy, Vol. 50, (2014), No. 3, pp. 191195.

[3] CSP Today World Map http://www.trec-uk.org.uk/images/ CSPTodayWorldMap.pdf

[4] Strebkov D.S., e.g. Solar power plants with concentrators for large-scale solar energy, "Energy supply and energy efficiency in agriculture" 10th IRTC, on May 24-25, Moscow, Russia, 2016, FGBNU VIESH, pp. 96-108.

[5] CSP Today Global Tracker (September 2016).

[6] Fernandez-Garci A. e.g. Parabolic-trough solar collectors and their applications. Renewable and Sustainable Energy Reviews 14 (2010), pp. 1695-1721.

[7] Approved baseline and monitoring methodology AM0100. Integrated Solar Combined Cycle (ISCC) projects. CDM. Executive Board AM0100/Version 01.0.0 Sectoral scope: 01 EB 65.

[8] Fraunhofer ISE - Annual Report 2014/15.

[9] https://www.ise.fraunhofer.de/en/press-and-media/publications/veroeffentlichungen-pdfdateienen/infomaterial/annual-reports/fraunhofer-ise-annual-report-2014-15.pdf. 
International Journal of Energy and Smart Grid

[10] Fraunhofer ISE-Annual Report 2013/14.

https://www.ise.fraunhofer.de/en/publications/veroeffentlichungen-pdf-dateien-en/infomaterial/ annual reports/ fraunhofer-ise-annual-report-2013-14.pdf.

[11] CSP Today Global Tracker (August 2016).

[12] Teske S., e.g. Solar Thermal Electricity: Global Outlook 2016. European Solar Thermal Electricity Association, 2016.

[13] Asian Development Bank Project feasibility study 130 MW Navoi Integrated Solar Combined Cycle power plant.

[14] Asian Development Bank "Roadmap to Solar Energy Development” 2014.

[15] Behar O., e.g. Instantaneous performance of the first Integrated Solar Combined Cycle System in Algeria. Energy Procedia 6 (2011), pp. 185-193. 